\title{
IMPACT OF COMPETITIVE CAPABILITIES EMPOWERED BY COMMUNITY-BASED TOURISM PROJECTS ON TOURISM BUSINESSES SUCCESS IN RURAL TOURISM DESTINATIONS
}

\author{
G.T.W. Sriyani \\ Faculty of Management and Finance, \\ University of Ruhuna, Sri Lanka. \\ gtwasanthas@badm.ruh.ac.lk
}

\begin{abstract}
:
This paper endeavors to reveal the impact of competitive capabilities which were promoted by Community Based Tourism (CBT) empowerment projects on the success of rural tourism businesses and also key competitive capabilities which effect business success. The positivism approach was applied and a 250 sample of micro and small-scale tourism entrepreneurs (MSSTEs) from the rural tourism destinations of Panama and Arugam Bay in Ampara district and Kanneliya, Vihrahena, Mederipitiya, and Godahena in Galle and Matara districts who were empowered by the CBT projects namely, International Labour Organization and Ruhunu Tourism Bureau was selected by using the random number generator with the list of the MSSTEs of the two selected CBT projects. A structured questionnaire was used in collecting data and five hypotheses were formulated and tested to reveal whether any significant impact creates by the competitive capabilities empowered by CBT projects on tourism business success in rural destinations and which competitive capability affects mostly on creating a variance in business success. Results were obtained mainly through correlation and multiple regression analysis. Findings revealed that empowerment efforts of CBT projects affect significantly the business success of MSSTES. Among the five constructs of competitive capabilities, capacity enhancement, community collaboration and cohesiveness, and business know-how and management are the
\end{abstract}


only predictors which affect significantly business success. Facilitating network building and sustainability practices are not good predictors. Though the impact of network building and sustainability practices on business success was reported as insignificant, a positive but weak correlation exists between these variables. This positive relationship implies that success of rural tourism businesses can be further enhanced by promoting these two capabilities and the concentration need to be given by policy planners and practitioners on the inappropriate assistance of the CBT projects for network building and sustainability practices among the MSSTEs in rural tourism destinations.

Keywords: Business Success; Community Based Tourism Projects; Competitive capabilities; Micro and Small-Scale Tourism Entrepreneurs; Rural tourism destinations 


\section{Introduction}

Tourism presently is used as a pro-poor strategy among many developing and least developed countries (LDCs) for reducing poverty, especially in rural tourism destinations. This broadest perspective of tourism opens the avenues for the community people who are living in rural tourism destinations to diverse their livelihood opportunities as well as to ensure sustainable development in the tourism industry. As such intentions, the concept of Community Based Tourism (CBT) has emerged with the work of Murphy (1985) and consequently the work of Inskeep (1991), Woodley (1993), Ritchie (1999), and Gunn and Var (2002) (cited by (Tasci et al., 2014, p. 220). Presently, several international organizations such as World Tourism Organization, United Nations (UN), International Labour Organization (ILO) and national level organizations such as Sri Lanka Tourism Development Authority (SLTDA), Sri Lanka Tourism Bureau, and provincial tourism bureaus apply the CBT concept with the broadest views. These include: eradicating poverty, improving the quality of life and living conditions of the rural people, diversifying the local economy, ensuring the tourism sustainability, and strengthening the capabilities of rural communities for initiating and sustaining unique and diverse range of tourism business activities (Dangi \& Jamel, 2016; UNWTO, 2017). However, the argument behind this CBT concept was that the marginalized people in the rural tourism destinations are new to the tourism businesses, suffer from severe poverty, inappropriate know-how, capacity, competitive capabilities, and etc. Hence, they are unable to reach their full potential to sustain in the industry (Sriyani, 2021; Havadi-Nagy \& Espinosa Segui, 2020). Meanwhile facing the severe competition is another big challenge for them. On the other hand, demand shifts in tourism from traditional types of 3Ss (Sun, Sea, and Sand) to Nature, Culture, and People creates the mandatory requirement of more community involvement in tourism to provide them with real village life experience (Kampetch \& Jitpakdee, 2019). Moreover, it opens the avenues for the community people to cater to a niche segment by using their diverse capacity and unique resources specifically the natural and human capital. SLTDA (2009), and Irshad (2010) highlighted that gearing up the untouched resources and talents have with the community people in rural tourism destinations, it could be harnessed big opportunities to uplift their living conditions and the tourism industry. 
Many authorized organizations (for example, SLTDA, UNWTO, etc.) revealed that several successful CBT stories are available in several countries like Thailand, Malaysia, Sri Lanka, and etc. These communities usually focus on niche markets by offering the tourism products and services in the range of eco-tourism, agritourism, adventure tourism, cultural and heritage tourism and specifically draws the attention on offering the local products and services to customers while sharing the economic benefits among the community (ASEAN Community Based Tourism Standard, 2016). Meanwhile, unsuccessful CBT stories were reported in several countries and in several destinations even from Sri Lanka (Kumara, 2016; Sriyani, 2018). For example, Cooper (2004) pointed out that lack of marketing capacity and knowledge on how the marketing structure operates have caused to the failure in CBT projects in the Caribbean (cited by Samarathunga et al., 2015). Rathnayake \& Kasim (2016) mentioned that there is much desperation for achieving the success by the tourism entrepreneurs at community level even after much effort was taken to empower them. They argued that this was happened due to lacking competitive capabilities among the community people such as technical skills, planning and designing skills, marketing know-how, etc. which required to fulfill the visitor requirements as well as to face successfully with huge competition. Therefore, the main objectives of this study were to reveal the impact of competitive capabilities empowered by CBT projects on tourism business success in rural destinations and to determine which capability among the five selected dimensions affects mostly to create a variance in tourism business success in rural destinations. Finally, this research aims to provide implications for future researchers and policy implications about which type of competitive capabilities have a significant impact on business success among the community tourism entrepreneurs and which ones are still lacking.

\subsection{Research Problem}

In the past literature, the importance of CBT was discussed in terms of several aspects such as an important generator of business opportunity for small and medium scale enterprises (SMEs), an effective vehicle for dispersing economic benefits within and among economies, particularly at the local level, and a 
catalyst for partnership between the public and private sectors (Nair \& Hamzah, 2015, P.430). As a replacement for managing the local economy by using "top-to-bottom" approach, presently, the "bottom-up" form of community participatory approach to tourism management and planning is applied for development and sustainability perspectives (Lekaota, 2015; Havadi-Nagy \& Espinosa Segui, 2020). Therefore, the host communities in the rural tourism destinations have been identified as the vital agents who should bear the hard role of being the guarantors of the economic processes taking place in their areas (Havadi-Nagy \& Espinosa Segui, 2020), ensuring sustainability in terms of Planet, People and Profit (Amir, 2015) and offering diversified tourism activities to attract and satisfy visitors (Fong \& Lo, 2015). Many researchers (for example, Sánchez-Cañizares \& Castillo-Canalejo, 2014; Okazaki, 2008) pointed out that CBT is a unique type of tourism in which the community plays a key role through the active involvement and participation in the whole process of tourism planning and implementation as well as the travelers got more excitement and diverse experience. The argument is there that bearing such an extensive and difficult role, the community people should possess specific resources and competencies. However due to the low level of education, capacity, technology and business know-how, etc., they alone are unable to start and sustain a tourism business (Kumara, 2016; Sriyani, 2021). Hence, the necessity of a third-party involvement in providing the motivation and facilitation for the business startups and growth has been identified and new development paradigm of CBT was created under the umbrella of sustainability supports and encourages self-help, self-reliance, and empower communities (Kampetch \& Jitpakdee, 2019; Yanes et al., 2019). Therefore, the policy planners have considered the CBT concept mainly as a strategy for poverty reduction, diversifying local economies, and ensuring sustainability in tourism. Also, CBT entrepreneurs are recognized as vital actors who focus on niche tourism markets by offering a diverse range of unique types of tourism products and services, diversify the local economy while ensuring equally sharing resources and benefits among the community while ensuring sustainability in the tourism sector. 
Many researchers (for example, Fong \& Lo, 2015) highlighted that community involvement plays a pivotal role in sustaining rural tourism development and directs the community for sharing knowledge, gaining commitment from the communities, and participation in decision making process. Boronyak (2010) revealed several successful CBT models in developing countries such as "Barrio" in Malaysia, "Chapbook Eco-tourism site" and "Chi Pat Eco-Tourism Site" in Cambodia, "El Niño foundation" and "Pamilacan Marine Life Tours" in the Philippines, "Tequila" and "Posada Amazonas" in Peru. ACNielsen ORG-MARG (2008) revealed that all projects are operated in moderate level success according to the study of 25 community tourism projects in India. In the Sri Lankan context, it is few to identifying successful community tourism projects. For example, one of the top - ranked surfing destinations in Arugam Bay operates in a good manner and the first surfing school and female surf club called "girls Make Waves" were established. Kuchchaveli tourism project which was initiated by SLTDA in 2018, is another great example of a successful tourism project in Sri Lanka (DailyFT, 2019). Kanneliya homestay project and Viharahena ecotourism project are other examples which were empowered by the RTB together with SLTDA in the Southern province of Sri Lanka were able to create several direct and indirect employment opportunities for the villagers, uplift their living conditions, infrastructure development in the area, preserving Sinharaja rain forest, etc. while ensuring the provision of exciting experience for the tourists (Fernando \& Kaluarachchi, 2016).

Though CBT projects aimed at several goals as discussed above, several researchers argued that in overall, the achievement of CBT goals of sustainable development and transformation of the lives of community people are problematic (Irshad, 2010; Ranasinghe, 2015; Ratnayake \& Kasim, 2015; Sheham, 2016; Sriyani, 2018). In Sri Lankan context, it has been identified several failed CBT projects such as Walathwewa Community Environmental and Tourism Initiative (Ratnayake \& Kasim, 2015; Ranasinghe, 2015), Rekawa Community Environmental and Tourism Initiative (Ratnayake \& Kasim, 2015), Bundala and Nilwala community tourism project (Sheham, 2016), and Padavigampola and Madurawala CBT projects (Sriyani, 2018). As such, the existing literature 
show that while several CBT projects function properly and attain the goals, others record poor performance. Moreover, though the competitive capabilities of the community people were identified as vital for successful operation and sustainability in tourism in rural tourism destinations, the emphasis was lacking by the previous research (Kontogeorgopoulos \& et al., 2014; Goodwin \& Santilli, 2009). Then, by focusing on the existing research gaps in the CBT research arena, this research addressed revealing whether the empowerment efforts of the CBT projects towards improving the competitive capabilities of micro and small-scale tourism entrepreneurs affect achieving the business success and which capabilities are still lacking.

\section{Review of the Literature}

\subsection{What is Community Based Tourism?}

Community-Based Tourism is "a form of locally situated development that uses tourism to generate economic, social, and cultural benefits within a community" (Johnson, 2010, p. 150 - cited by Havadi-Nagy \& Espinosa Segui, 2020). Lucchetti $\&$ Font (2013) stated that even though the CBT concept covers a broad range of different tourism models, usually it refers to tourism that involves community participation and aims to generate benefits for local communities in the developing world by allowing tourists to visit these communities and learn about their culture and the local environment. Tasci et al., (2013, P.84) described community-based tourism as "aims to the holistic goal of empowering underprivileged groups sustainably".

\subsection{Why Community Based Tourism?}

CBT is considered as central for the sustainability of tourism owing to the potential adverse effects of the large-scale, all-inclusive, mass tourism on local people's living conditions, and bottlenecks of the "top-down approach" of local economic development (Havadi-Nagy \& Espinosa Segui, 2020; Tasci, Semrad, \& Yilmaz, 2013). Asker et al., (2010) emphasized that participation of communities in tourism planning, ongoing decision-making, development, and operations are essential to achieve sustainability in tourism. Development practitioners emphasized that community involvement in tourism can enact the principles of 
sustainable development and produce transformations to the lives of community people (Tosun, 2000, cited by Dodds \& Galaski, 2016; Runyowa, 2017). Therefore, the initiative of CBT aims at eradicating the poverty among rural poor, diversifying local economies, improving the quality of life of the community, getting the use of cultural heritage and natural resources while protecting those for future generations. Hence, CBT is a worthwhile choice for stimulating the development of rural economies due to the perceived economic benefits to locals (Dodds \& Galaski,2016).

\subsection{Impact of the empowerments done by the CBT projects on Tourism Business}

\section{Success}

As the definition of CBT emphasized, it is a participatory approach in which the community plays a key role in the whole process of tourism planning and implementation. Therefore, the community has to play a diverse role as entrepreneurs, managers, organizers, community leaders, negotiators, innovators, etc. In playing such a widest role, the community has to be sharpened with the required resources and competencies. Past literature evidenced that the empowerment efforts of CBT projects facilitate the community people to acquire the required resources and competencies which will be helpful in achieving business success, though several bottlenecks, and lacking areas of knowledge and capacity were revealed.

Goodwin \& Santilli (2009) pointed out several essential benefits provided by the CBT to facilitate the development of the community-level tourism businesses. These include capacity building, finance providing, business management, leadership, and infrastructure development. Sharpening the community with business know-how and operations has been identified as one of the facilitations provided by $\mathrm{CBT}$ projects. At the initial stage of the business, providing training on technology, bookkeeping, marketing, etc. affects properly running tourism businesses. Mitchell \& Muckosy (2008) argued upon market knowledge is crucial for evaluating commercial viability of CBT initiatives and providing them with marketing and market knowledge is more helpful to the community to understand market size, seasonality in demand, average length of stay, etc. 
Capacity development was recognized as a prominent factor that affects CBT success (Saayman \& Giampiccoli, 2016; Tasci et al., 2013; Moscardo, 2008). As per the definition of the CBT concept, it is a unique type of tourism in which the community has to play a key role through active involvement and participation in the whole process of tourism planning and implementation and ensuring visitor satisfaction. Doing such an extensive and difficult role, the community people should have enough capacity. Education and training were identified as key components of entrepreneurial capacity (Dodds \& et al., 2016). Saayman \& Giampiccoli (2016) mentioned that lack of capacity is one of the biggest challenges faced by the community people in rural tourism destinations because of low level education and lack of access to required training. Therefore, capacity development of the rural community is an eminent role of a CBT project.

Facilitating network building is another role done by the CBT projects in terms of sharpening the competitive capabilities have with the community people who engage in tourism businesses. Creating networks with financial institutions, entrepreneurs in supportive industries, input suppliers, other service providers, and the community in the area assist to increase the ability to share resources and ensure the sustainability in community tourism business (Kampetch \& Jitpakdee, 2019; Asero et al., 2015). CBT projects also facilitate for creation of community leadership, and strong voice in the community, and serve as a bridge between the community and external actors (Kontogeorgopoulos, et al., 2014). Hence, rather than operating alone, networking creates more benefits for the community people in achieving business success.

Sustainability was also identified as one of the success factors of comunitybased tourism businesses (Karacaoğlu \& Birdir, 2017). Fong \& Lo (2015), and Fiorello \& Bo, (2012) emphasized four dimensions in sustainable rural tourism development, namely social, cultural, economic, and environmental sustainability. As a result of highly insensitive nature of mass tourism on these sustainable tourism aspects in tourism destinations, CBT is used as a tool for avoiding the negative effects of tourism on local destinations (Fiorello \& Bo, 2012, Fong \& Lo, 2015). Rocharungsat (2005), and Hipwell (2007) also emphasized securing and conservation of natural resources and sustainment of cultural values as essential for community tourism business success (Cited by Karacaoğlu \& Birdir, 2017). 
Building up community cooperation and cohesiveness is another crucial role of the CBT initiatives (Dodds \& et al., 2016). Elliott (1997) and Choi \& Sirakaya (2006) mentioned that stakeholders should form part of destination management and be given responsibilities at the local level (cited by Lekaota, 2015). This implies the importance of having collaboration and corporation among the community people and the strong community leadership to take up such a difficult role. Fong \& Lo (2015) highlighted that community involvement plays a pivotal role in sustaining rural tourism development and directs the community for sharing knowledge, gaining commitment from the communities, and participation in decision making process and those will eventually assist in achieving tourist satisfaction and sustainable rural tourism development. The research conducted in Zambia, Malaysia, Thailand, and Indonesia revealed that facilitation for building up the cooperation of the local community is essential for business success (Dixey,2005). Witchayakawin et al. (2020) emphasized compelling to have a collaborative vision to the community drives for developing a strategic designation branding, collaborative destination marketing, web page designing for the community tourism society, etc. are the outcomes of community empowerment projects. Moreover, cooperation of the local community is essential to detect and develop the cultural assets used to create a sustainable tourist destination (Okazaki, 2008). Also due to the strong collaboration and cooperativeness of the community people are helpful to create a liaison role between government and local entities, make a voice against giant competitors, involvement in local economic development through the bottom-up approach. Negotiation, ensure accountability, setting a community agenda are also important factors to the success of community tourism development projects (Bamber et al., 2010). By doing the study at Sam Chuk, Nitikasetsoontorn (2015) found that collective responsibility significantly and positively increases sharing of resources of residents. Nitikasetsoontorn (2015) further pointed out when residents accept more responsibility for communitybased tourism development, pool more resources, such as time, labor, and money, and share more tourism benefits equitably among themselves, they are more likely to achieve business success. Rocharungsat (2005) specifies the success factors perceived by the stakeholders of CBT projects in Malaysia, Thailand, and Indonesia as active participation and support of the community members, fair and equal 
distribution of the benefits acquired from tourism, good management of the project operations (planning, management, promotion, advertising, etc., ensuring the cooperation and support between the stakeholders (political, economic, educational, etc.), etc. (Cited by Karacaoğlu \& Birdir, 2017).

However, Kontogeorgopoulos \& et al. (2014) emphasized that community leadership is generally neglected in the literature as a success factor even though it is usually listed as just one of many reasons for a community's success in fostering CBT. Sheham (2016) also evidenced that bad community perception, traditional power patterns of community, a little contribution from tourism to community well-being, a weak relationship between the objectives of conservation and rural socio-economic development cause to hamper the business success at the community level.

Tasci \& et al. (2013) argued that several CBT initiatives reported failures due to lack of community involvement and participation, a sense of ownership of the initiative among the community members, and lack of local financial resources. Tasci \& et al. (2014) revealed that shared vision, communal goals and benefits, stakeholder involvement and participation, cooperation, and collaboration were identified as critical success factors of CBT and the businesses may fail with the absence of such factors. Giampiccoli et al., (2015) revealed that, in the Jamaican context of CBT, community people have to face a lot of challenges of lack of finance and business know-how, lack of marketing support and information access, inadequate capacity and coordination among the community people, and "one size fits all" attitude of tourism professionals. Regarding the Sri Lankan CBT projects, bottlenecks such as insufficient education and training opportunities, lack of motivation, lack of financial support, poor level of communication and linkages among stakeholders, and lower government intervention were revealed (Dissanayake \& Samarathunga, 2016).

As per the afore-described existing literature on the impact of the empowerments done by the CBT projects on tourism business success as well as the discussions had with the project coordinators of CBT projects in Sri Lanka (ILO and RTB), five key determinants were identified to be studied further. Those were business 
know-how and management, collaboration and cohesiveness, network building, sustainability practices, and capacity enhancement. The following are the research hypotheses of this study that were developed based on these five key determinants of tourism business success in rural destinations.

H1: Enablement of having the business know-how through the CBT project affect significantly on the success of rural tourism businesses.

H2: Enablement of enhancing the collaboration and cohesiveness among the community people through the CBT project affect significantly on the success of rural tourism businesses.

H3: Enablement of network building through the CBT project affect significantly on the success of rural tourism businesses.

H4: Making awareness of sustainability practices through the CBT project affect significantly on the success of rural tourism businesses.

H5: Capacity enhancement of the community through the CBT project affect significantly on the success of rural tourism businesses.

\section{Methods}

The positivism approach was applied because this study focuses on understanding a social setting by recognizing the individual's constituents of a phenomenon of CBT success owing to empowerment and then simplifying the phenomenon in terms of different constructs, and relationships between these constructs. Five hypotheses were developed to test these relationships and reveal the key competitive capabilities that affect tourism business success which has been empowered by CBT projects. Therefore, the study constructs include independent variable of "empowerment efforts of CBT projects on enhancing the competitive capabilities" and dependent variable of "Tourism businesses success (TBS)". Five sub dimensions including business know-how and management (BKHM), community collaboration and cohesiveness (CCC), network building (NB), sustainable practices (SP), and capacity enhancement (CE) were considered as 
competitive capabilities and a 5-point Likert scaled structured questionnaire was used to reveal respondents' perceptions on the impact of community empowerment projects on tourism business success relating to these five dimensions. The aggregated average growth in number of visitors, number of employees, and capital investment were used as the criteria of measuring business success by taking into account the three-year average from 2016 to 2018.

A sample of 250 micro and small-scale tourism entrepreneurs (MSSTEs) were selected from Panama and Arugam Bay villages in Ampara district which were empowered by the CBT projects of International Labour Organization (ILO) and MSSTEs from Kanneliya, Vihrahena, Mederipitiya, and Godahena villages in Galle and Matara districts which were empowered by the CBT projects of Ruhunu Tourism Bureau (RTB). The random number generator with the list of the MSSTEs of the two selected CBT projects was applied in selecting the sample. Both these CBT projects operate under the Sri Lanka Tourism Development Authority. Because of non-responding and missing data, 25 questionnaires were rejected and 225 questionnaires proceeded for analysis purposes. Then the response rate was 90 percent. The results were received through correlation and regression analysis and accordingly tested the formulated hypotheses. The Cronbach alpha test was used to determine reliability and the internal consistency of the measurements used in the study.

\section{Data Analysis}

Basic information of the MSSTEs in the sample revealed that majority (92\%) was in the age group of year 30-50, $57 \%$ was male and $43 \%$ was female, $88 \%$ was married ones, $59 \%$ has at least senior secondary level education and $16 \%$ has tertiary level education. The community people in the selected villages are engaging in homestay operations, safari tours (Wildlife, village life, heritage, and boat tours), adventure activities (land and water-based) surfing and surfing training, beach party and cultural entertainments, souvenir shops and retail shops, conduct cookery classes, tour guides, restaurants, etc. Table 1 shows the reliability test results and accordingly all constructs reported the value of greater than 0.6 and this assures the internal consistency as per the rule of thumb of internal 
consistency described by Hair et al (2003) and Zikmund (2013) and the scales deemed reliable for further analyses.

\section{Table 1: Results of Reliability Test}

\begin{tabular}{llc}
\hline Construct & Indicators & Cronbach's alpha \\
\hline Business Know-how \& Management & BKHM1, BKHM2, BKHM3 & 0.866 \\
Community Collaboration \& Cohesiveness & CCC1, CCC2, CCC3, CCC4 & 0.887 \\
Network Building & NC1, NC2, NC3 & 0.832 \\
Sustainability practices & SP1, SP2, SP3 & 0.819 \\
Capacity enhancement & CE1, CE2, CE3, CE4 & 0.809 \\
Tourism business success & TBS1, TBS2, TBS3 & 0.864 \\
\hline
\end{tabular}

Source: Survey:2019/2020

The main objective of this study was to reveal the impact of competitive capabilities empowered by CBT projects on tourism business success in rural destinations. As revealed through the literature review and mainly the discussions had with the project coordinators of CBT projects in Sri Lanka (ILO and RTB), CBT projects facilitate the community to have competitive capabilities which concern as vital for business success. Table 2 shows the group statistics of competitive capabilities which were studied in this study relating to the selected sample. All the mean values reported as greater than 3.0 except promoting them for sustainability practices. This indicates that the MSSTEs in the sample agreed upon 4 dimensions of competitive capabilities among them have been able to promote by the CBT projects.

\section{Table 2: Group Stastistics of Competitive Capability of the Community}

\begin{tabular}{lccc}
\hline Construct & N & Mean & Standard Deviation \\
\hline Business Know-how \& Management & 225 & 3.931 & 1.138 \\
Community Collaboration and & 225 & 4.342 & 1.103 \\
Cohesiveness & & & \\
Network Building & 225 & 3.473 & 1.537 \\
Sustainability Practices & 225 & 2.774 & 1.410 \\
Capacity Enhancement & 225 & 3.938 & 1.138 \\
Tourism Business Success & 225 & 3.678 & 1.173 \\
\hline
\end{tabular}

Source: Survey : 2019 / 2020 
Correlations between the five dimensions of competitive capabilities and tourism business success as depicted in Table 3 evidenced that the Pearson correlation between business success and capacity enhancement is significant at 0.833 followed by community collaboration and cohesiveness at 0.814 , and subsequently by business know-how and management at 0.525 , sustainability practices at 0.355 and network building at 0.298 . All reported positive and significant correlation

Table 3: Correlation Analysis between Competitive Capabilities and Business Success

\begin{tabular}{lc}
\hline Construct & Tourism Business Success \\
\hline Business Know-how \& Management & $.525^{* *}$ \\
Community Collaboration and Cohesiveness & $.814^{* *}$ \\
Network Building & $.298^{* *}$ \\
Sustainability Practices & $.355^{* *}$ \\
Capacity Enhancement & $.833^{* *}$ \\
\hline
\end{tabular}

**. Correlation is significant at the 0.01 level (2-tailed). $\mathrm{N}=225$

Source: Survey : 2019 / 2020

By addressing the main objective of this study, multiple regression analysis was used to reveal the overall impact of the empowerment efforts done by the CBT projects for enhancing the competitive capabilities of MSSTEs in rural tourism destinations on their business success. Table 4 depicts the overall model summary of the multiple regression analysis on the five dimensions of competitive capabilities of MSSTEs with business success. The R square value of 0.581 indicates that $58.1 \%$ of the variance in business success of MSSTEs in rural tourism destinations who were empowered by a CBT project was significantly explained by the selected five dimensions of competitive capabilities.

\begin{tabular}{|lcccc|}
\hline Model & $\mathrm{R}$ & $\mathrm{R}^{2}$ & $\begin{array}{c}\text { Adjusted } \\
\mathrm{R}^{2}\end{array}$ & $\begin{array}{c}\text { Std. Error of } \\
\text { the Estimate }\end{array}$ \\
\hline $\begin{array}{l}\text { Competitive capabilities of the } \\
\text { community }\end{array}$ & $.762^{\mathrm{a}}$ & .581 & .574 & .76495 \\
\hline
\end{tabular}

a. Predictors: (Constant), BKHM, CCC, NB, SP, CE

The second objective of this study was focused to determine which variable among the five competitive capabilities affects mostly to create a variance in the tourism business success in rural tourism destinations. Table 5 illustrates the multiple 
regression results on this endeavor. Accordingly, capacity enhancement recorded the highest beta value of 0.742 , community collaboration and cohesiveness reported the second-highest beta value of 0.650 , and business know-how and management was ranked next with the beta value of 0.198. All these beta values are significant at the 0.01 level of significance. Therefore, among the five hypotheses formulated for this study, the hypothesis one (H1: Enablement of having the business know-how through the CBT project affect significantly on the success of rural tourism businesses), hypothesis 2 (H2: Enablement of enhancing the collaboration and cohesiveness among the community people through the CBT project affect significantly on the success of rural tourism businesses), and hypothesis five (H5: Capacity enhancement of the community through the CBT project affect significantly on the success of rural tourism businesses) can be accepted. As seen in Table 5, the beta coefficients of other two remaining variables of the model, network building and sustainability practices, are respectively $0.131(p=0.056)$ and $0.167(p=0.057)$. The $P$ values show that the impact of both of the variables on business success was insignificant and therefore, hypothesis three (H3: Enablement of network building through the CBT project affect significantly on the success of rural tourism businesses) and hypothesis four (H4: Making awareness of sustainability practices through the CBT project affect significantly on the success of rural tourism businesses) cannot be accepted. These coefficient statistics revealed that the empowerment efforts of the CBT projects for capacity enhancement, promoting community collaboration and cohesiveness, and business know-how and management are the only predictors which affect tourism business success and facilitating for network building and sustainability practices cannot be identified as the good predictors.

\begin{tabular}{|c|c|c|c|c|c|}
\hline \multirow[t]{2}{*}{ Model } & \multicolumn{2}{|c|}{$\begin{array}{l}\text { Unstandardized } \\
\text { Coefficients }\end{array}$} & \multirow{2}{*}{\begin{tabular}{|l|} 
Standardized \\
Coefficients
\end{tabular}} & \multirow[t]{2}{*}{$\mathrm{t}$} & \multirow[t]{2}{*}{ Sig. } \\
\hline & B & Std. Error & & & \\
\hline $\begin{array}{l}\text { Business Know-how \& } \\
\text { Management }\end{array}$ & .210 & .069 & .198 & 3.025 & .000 \\
\hline $\begin{array}{l}\text { Community Collaboration } \\
\& \text { Cohesiveness }\end{array}$ & .670 & .067 & .650 & 9.942 & .000 \\
\hline Network Building & .139 & .066 & .131 & 1.932 & .056 \\
\hline Sustainability Practices & .186 & .055 & .167 & 1.925 & .057 \\
\hline Capacity Enhancement & .764 & .062 & .742 & 12.417 & .000 \\
\hline
\end{tabular}

Dependent Variable: Tourism business success 


\section{Results Discussion}

Most of the findings of this study are compliant with the findings of CBT experience in other countries and the Sri Lankan context. The present study found that capacity of community tourism entrepreneurs, business know-how and management as well as collaboration and cohesiveness of the community people affect significantly on the tourism business success. A similar view was presented by Kampetch \& Jitpakdee (2019) and emphasized that main factors which lead to the success of Baan Rim Klong Homestay include community leadership, community participation, tourism business management, and tourism network. However, network was not a good predictor of the present study though it was identified as important by Kampetch \& Jitpakdee (2019). Also, Nitikasetsoontorn (2015) identified participation in decision-making processes, local ownership, collective responsibility, sharing of resources, and leadership and management as significant affecting factors on the success of CBT for the Sam Chuk traditional market and Klong Suan old market in Thailand. Connelly and Sam (2018) also accepted cooperativeness as a highly required factor for community business success. Kontogeorgopoulos \& et al., (2014), and Tasci \& et al. (2013; 2014) much appreciated the role of local leadership on the business success. Further, the findings of this study show that sustainability practices much not affected business success as revealed in this study also. Similar experiences were reported from the local people of Misi Village and Karacaoğlu and Birdir (2017) realized that conservation of tourism resources and scale of tourism development had a lower acceptance rate and they haven't fully embraced sustainable tourism. Even though sustainability didn't work as a good predictor of the business success of the current research, Connelly and Sam (2018) agreed on sustainability is essential for CBT success.

\section{Conclusion and Research Implications}

By taking into account the importance of the CBT approach, this study mainly focused on revealing the impact of empowerment efforts done by the CBT projects for enhancing competitive capabilities on business success of MSSTEs in rural tourism destinations and identifying which competitive capabilities create 
more variation in the business success. Findings evidenced that empowerment efforts of the two CBT projects which have been selected for the study from Sri Lanka significantly influence improving the business success of the MSSTEs in rural tourism destinations. The individual constructs of capacity enhancement, promoting community collaboration and cohesiveness, and business know-how and management show significant impacts on business success. The community people believed that CBT efforts on capacity development, and promoting community collaboration and cohesiveness affect highly compared to other empowerment efforts tested in this study. Slight impact was reported relating to enhancing business know-how and management skills of the MSSTEs. Because of their poor nature, the assistance of the CBT projects for ensuring the availability of required business assets as well as infrastructure remarkably affects business success. To eradicate poverty among the community people in rural tourism destinations, more concern was given to diversify the local economy, specifically by taking into account the seasonality nature of their income pattern and tourism has been recognized as an additional income source for them. Therefore, the newcomers to the tourism sector who starts homestays, agro-tourism, adventure and safari tours, etc. expect know-how about the business and technology via these community tourism projects. Moreover, as emphasized in other research also, community collaboration and cohesiveness, know-how of tourism business technology and practices, business management skills are essential to introduce unique products and services by taking advantages of the unique resources and talents have with the rural community. Though the business know-how and management affect significantly the business success as per the findings, the relative size of the impact is comparatively low and then much attention is required in the future on this aspect.

Further, this study revealed that the facilitation efforts of the two CBT projects relating to network building and promoting sustainable practices were not perceived as strong enough among the community people and much attention is required to be given in future work of the projects. However, correlation statistics relating to network building and promoting sustainable practices does not imply negative relationships with the business success and this communicates us much 
attention required to be given for better results. Networking with input suppliers, complementary product or service suppliers, visitors, etc. much affects to self-sustain of MSSTEs. Sustainable practices of the rural tourism entrepreneurs are too vital to visitor attraction and satisfaction, long-term survival and sustainability. By taking into account the key findings of this study, the attention of the development initiatives required to be focused on enriching MSSTEs in rural destinations further with such vital competitive capabilities to harness the maximum benefits of the unique competencies and resources having in such rural tourism destinations and finally uplift the rural tourism brand in Sri Lanka. Further, by expanding the research scope into other rural tourism destinations, a wide view could be received regarding the competitive capabilities of community tourism entrepreneurs. 


\section{References :}

ACNielsen ORG-MARG. (2008). Evaluation Cum Impact Study of Rural Tourism Projects. Final Report, Ministry of Tourism, Government of India, https:// tourism.gov.in/sites/default/files/2020-04/merged1.pdf

Amir, A. F. (2015). "Sustainable tourism development: a study on community resilience for rural tourism in Malaysia", Procedia - Social and Behavioral Sciences, 168, pp.116-122.

Asero, V., Tomaselli, V., \& Gozzo, S. (2015). Building Tourism Networks through Tourist Mobility. Research Gate, 55(6), pp. 751-763.

Asker, S., Boronyak, L., Carrard, N. \& Paddo, M. (2010). Effective Community Based Tourism: A Best Practice Manual for Peru, APEC Tourism Working Group, Working Paper, June, pp. 1-8, https://www.researchgate.net/ publication/308315284

Bamber, J., Owens, S., Schonfeld, H., Ghate, D., \& Fullerton, D. (2010). Effective Community Development Programmes: A Review Of The International Evidence Base. Dublin: The Centre For Effective Services, http://hdl.handle. net/10147/298996.

Boonratana, R. (2010). Community-based tourism in Thailand: The need and justification for an operational definition, Kasetsart Journal: Social Sciences, 31(2), 280-289.

Boronyak, L, Asker, S., Carrard, N., \& Paddon, M. (2010). Effective Community Based Tourism: A best practice manual, APEC tourism working group, Working Paper, June, pp. $89-100$, https://www.researchgate.net/ publication/308315284

CTO- Caribbean Tourism Organization. (2006). Competing with the Best: Good Practices in Community Based Tourism in the Caribbean. http://www. onecaribbean.org/goodpractices/bestpractices.aspx 
DailyFT EPaper (2019, 10th May). Sri Lankan Tourism a Success Story: No Tourism, No Economy? https://www.ft.lk/columns

Dangi, Tek B., Tazim Jamal. (2016). An Integrated Approach to Sustainable Community Based Tourism. Journal of Sustainability. 8, P. 475, doi:10.3390/ su8050475.

Dissanayake, D. M., \& Samarathunga, W. H. (2016). Prospects and Challenges Of Community Based Tourism Promotion In Mihintale Area. International Research Symposium, Rajarata University of Sri Lanka, https://www. researchgate.net/publication/331589834

Dixey, L. (2005). Inventory and analysis of community-based tourism in Zambia. Zambia: Production, Finance and Technology (PROFIT), pp. 29-60, africanphilanthropy.issuelab.org > resources

Dodds, R., Ali, A., \& Galaski, K. (2016). Mobilizing Knowledge: Key elements of success and barriers in community-based tourism, Current Issues in Tourism DOI, https://www.researchgate.net/publication

Fernando, S. M., \& Kaluarachchi, K. A. (2016). Eco Tourism Practices in Sri Lanaka: The Case Study of Rainforest Eco Lodge, Colombo Business Journal: International Journl of Theory and Practice, 7(2), pp. 50-62.

Fiorello, A., D. Bo, D. (2012) Community-based ecotourism to meet the new tourist's expectations: An exploratory study. Journal of Hospitality Marketing \& Management 21 (7), 758-778

Fong, S. F., Lo, M. C. (2015) Community involvement and sustainable rural tourism development: perspectives from the local communities. European Journal of Tourism Research 11, pp. 125-146

Giampiccoli, A., Jugmohan, S., \& Mtapuri, O. (2015). Characteristics and Policies of Community-Based Tourism in the Case of Jamaica. Caucasus Journal of Social Sciences, pp. 45-70. http://hdl.handle.net/10321/2287 
Goodwin, H.J, \& Santilli R. (2009). Community-Based Tourism: a success? ICRT Occasional Paper 11, https://www.researchgate.net/publication/265278848

Hair, F, H., Black, W.C., Tatham, R.L., \& Anderson, R.P. (2003). Multivariate Data Analysis, Pearson Education (Singapore) Pte Ltd. India.

Havadi-Nagy, K.X., \& Espinosa Segui, A. (2020). Experiences of communitybased tourism in Romania: chances and challenges, Journal of Tourism Analysis: Revista de Análisis Turístico 27(2), pp. 143-163, https://www. emerald.com/insight/publication/issn/2254-0644

Hiwasaki, L. (2006). Community-based tourism: A pathway to sustainability for Japan's protected areas, Society and Natural Resources, 19(8), pp.675-692.

Irshad, H. (2010). Rural tourism- An Overview. Alberta: Agriculture and Rural Development Division. humaira.irshad@gov.ab.ca

Kampetch, P. \& Jitpakdee, R. (2019). The Potential for Key Success of Community-Based Tourism Sustainability: Case Study Baan Rim Klong Homestay, Samut Songkram, Thailand. ABAC Journal, 39(4), (October-December), pp 111-122.

Karacaoğlu, S. \& Birdir, K. (2017). Success Factors of Community Based Tourism (CBT) Perceived by Local Peoples: The Case of \% 100 Misia Project, International Rural Tourism and Development Journal, E-ISSN: 2602-4462, 1 (2): pp. 53-61, https://www.researchgate.net/publication/326671050

Kontogeorgopoulos, N., Churyen, C., \& Duangsaeng, V. (2014). Success Factors in Community-Based Tourism in Thailand: The Role of Luck, External Support, and Local Leadership, Tourism Planning \& Development, 11(1), pp. 106-124, https://doi.org/10.1080/21568316.2013.852991

Kumara, H. I. (2016). Challenges to Implementing Community-Based Eco Tourism as a bottom Up Dvelopment Approach in the Sinharaja rain forest(Sri Lanka). https:/hdl.handle.net/10289/9894 
Lekaota, L. (2015). The importance of rural communities' participation in the management of tourism management A case study from Lesotho, Worldwide Hospitality and Tourism Themes, 7(5), pp. 453-462, www.emeraldinsight. com/1755-4217.htm

Lucchetti, V. G. \& Font, X., (2013). Community-based tourism: Critical success factors, International Centre for Responsible Tourism Occasional Paper No:27, pp. 20- 26, http://www.icrtourism.org/.../OP27.pdf

Mitchell, J., \& Muckosy, P. (2008). A misguided quest: Community-based tourism in Latin America. London. Overseas Development Institute, www.odi.org.uk

Nair, V., \& Hamzah, A. (2015). Successful community-based tourism approaches for rural destinations: The Asia Pacific experience, Worldwide Hospitality and Tourism Themes, 7(5), pp. 429-439.

Nitikasetsoontorn, S. (2015). The Success Factors of community based tourism in Thailand, www.researchgate.net > publication.

Okazaki, E. (2008), “A community-based tourism model: its conception and use", Journal of Sustainable Tourism, 16 (5), pp. 511-529.

Phanumat W., Sangsnit N., Mitrchob C, Keasang S., \& Noithammaraj P. (2015). A multi-stakeholder participatory approach in community-based tourism development: a case study from Thailand. Sustain Dev Plan VII. PP. 915-928.

Ranasinghe, R. (2015). Evaluation of Homestay Accommodation Supply in Sri Lanka. International Journal of Multidisciplinary Research and Development, 2(2), pp. 442-447.

Ratnayake, I. \& Kasim, A. (2016). Community Tourism Development: Propositions based on empirical evidence from Sri Lanka, BIMP-EAGA Journal for Sustainable Tourism Development, 5(1), PP. 32-48.

Runyowa, D. (2017). Community-based tourism development in Victoria Falls, Kompisi Cultural Village: an entrepreneur's model. African Journal of Hospitality, Tourism and Leisure, 6(2), PP. 1-7. 
Samarathunga, W. H. M. S., Wimalarathana, \& W., Silva, D. A. C. (2015). CommunityBasedTourismManagementExperienceinSriLanka, International Research Symposium Rajarata University of Sri Lanka, http://repository.rjt. ac.lk

Sánchez-Cañizares, S.M. \& Castillo-Canalejo, A.M. (2014). Community-based Island tourism: the case of Boa Vista in Cape Verde, International Journal of Culture, Tourism and Hospitality Research, 8(2), pp. 219-233.

Saayman, M., \& Giampiccoli, A. (2016). Community-based and pro-poor tourism: initial assessment of their relation to community development. European Journal of Tourism Research, 12, pp. 145-190.

Sheham, A. M. (2016). Sustainability of community-Based Tourism In Sri Lanka. EPRA International Journal of Economic and Business Review, 4(2), pp. 116- 119, http://epratrust.com/articles/upload

SLTDA (2009). Sri Lanka sustainable tourism development project-environmental assessment and management framework, http://www.sltda.lk/default/files

Sriyani, G. T. W.(2018). Challenges Faced by Homestay Operators in Sri Lanka. Proceedings of International Conference on Management and Economics (ICME). University of Ruhuna, Matara,Sri Lanka.

Sriyani, G.T.W. (2021). Impact of Social Capital Empowerments on the Businesses Success among the Micro and Small-Scale Tourism Entrepreneurs in Sri Lanka, Wayamba Journal of Management, 12(1), PP. 225-243.

Tasci, A.D.A., Croes, R., \& Villanueva, J.B. (2014). "Rise and Fall of communitybased tourism - facilitators, inhibitors and outcomes", Worldwide Hospitality and Tourism Themes, 6 (3), pp. 261-276, www.emeraldinsight.com

Tasci, A.D., Semrad, K.J., \& Yilmaz, S.S. (2013). Community-Based Tourism Finding the Equilibrium in the COMCEC Context Setting the Pathway for the Future. Ankara: COMCEC Coordination Office, www.comcec.org 
UNWTO Annual Report, (2017). e-Library, https://www.eunwto. org/doi/book/

Witchayakawin, P., Abdul Aziz, Y., Mahomed, A.S.B.B., \& Abdullah Zikmund, N.H.B. (2020). Factors on development of community-based tourism (CBT) in Phitsanulok province of Thailand, Journal of critical reviews, 7(12), PP 75-85, http://www.jcreview.com/fulltext/197-1592270424.pdf

William G., Jon C. Carr, Barry Babin, and Mitch Griffin. (2013), 'Business research methods', Nelson Education.

Yanes, A., Zielinski, S., Diaz Cano, M., \& Kim, S. (2019). Community-Based Tourism in Developing Countries: A Framework for Policy Evaluation, Sustainability. www.mdpi.com.pdf

Zikmund, William G., Jon C. Carr, Barry Babin, and Mitch Griffin. (2013). 'Business research methods', Nelson Education. 